\title{
Aseraggodes bolcomi, a New Sole (Pleuronectiformes: Soleidae) from the Hawaiian Islands ${ }^{1}$
}

\author{
Fobn E. Randall ${ }^{2}$
}

\begin{abstract}
The soleid fish Aseraggodes bolcomi, the third Hawaiian species of the genus, is described from six specimens collected off $\mathrm{O}^{6} \mathrm{ahu}$, from sand in $0.6-27 \mathrm{~m}$. It is distinct in having $68-72$ dorsal-fin rays, $47-50$ anal-fin rays, $76-$ 80 lateral-line scales, the snout not overlapping the lower lip, and in its small size (largest, $58.6 \mathrm{~mm} \mathrm{SL}$, a mature female).
\end{abstract}

Gilbert (1905) Described two new species of Sympburus from deep water as the first representatives of the family Soleidae for the Hawaiian Islands. These fishes, popularly called tonguefishes, are now placed in a separate family, Cynoglossidae. Gosline and Brock (1960) added the first true soleid to the Hawaiian fish fauna, which they "very provisionally identified" as the Japanese Aseraggodes kobensis (Steindachner). Randall (1996) showed that their kobensis is a new species, naming it $A$. therese, and described another shallow-water species, $A$. borebami. Both are nocturnal and usually bury beneath sand in caves during the day. It is therefore easy to understand why they were overlooked for so many years.

Fellow diver Ronald Holcom surprised J.E.R. by collecting a sole in $10 \mathrm{~m}$ at Pūpūkea on the north shore of $\mathrm{O}^{6} \mathrm{ahu}$ in 1997 that he thought was different in color from $A$. borebami and $A$. therese. J.E.R. confirmed that it is indeed different, not only by its color but by its lateral-line scale count of 77 (at most 66 in therese and 70 in borebami). Holcom collected three more specimens off Pūpūkea, two of which were caught in $27 \mathrm{~m}$. Darrell Takaoka collected the largest specimen, $58.6 \mathrm{~mm} \mathrm{SL}$, shortly after midnight at Ala Moana Beach Park in only $0.6 \mathrm{~m}$. David W. Greenfield and

\footnotetext{
${ }^{1}$ Manuscript accepted 15 October 2001.

2 Bishop Museum, 1525 Bernice Street, Honolulu, Hawaici 96817-2704.
}

Pacific Science (2002), vol. 56, no. 3:247-253

(C) 2002 by University of Hawai'i Press

All rights reserved
J.E.R. collected one additional specimen from Kāne'ohe Bay in $2 \mathrm{~m}$. A review of the literature reveals that this third species of the genus Aseraggodes from Hawait $i$ is also undescribed.

\section{MATERIALS AND METHODS}

Type specimens of the new species have been deposited in the Bernice P. Bishop Museum, Honolulu (вРвм), Calfornia Academy of Sciences, San Francisco (CAS), Museum National d'Histoire Naturelle, Paris (MNHN), National Science Museum of Tokyo (NSMT), and the National Museum of Natural History, Washington, D.C. (UsNM).

Lengths recorded for specimens are standard length (SL), measured from the front of the head at the base of the anterior dorsal-fin rays to the midbase of the caudal fin; body depth is the maximum depth from the base of the dorsal rays to the base of the anal rays; body thickness is the maximum thickness between the ocular and blind surfaces (but not over the abdomen); head length is measured on the ocular side from the upper end of the gill opening to the front of the head at the base of the dorsal rays; snout length is taken from the same anterior point to the front of the upper eye; eye diameter is the horizontal diameter of the upper eye (the dark eyeball, not the fleshy outer cutaneous part); interorbital width is the least width between the dark edges of the two eyes; upper-jaw length is measured on the blind side from the front of the upper lip to the rear of the maxilla; caudal-peduncle depth is the least depth, and caudal-peduncle length the horizontal distance between the rear base of the anal fin 
and the base of the caudal fin; predorsal, preanal, and prepelvic lengths are measured from the base of the first ray of these fins to the most anterior point of the upper lip; lengths of dorsal and anal rays are measured from the extreme base of the rays to the tips without trying to straighten the rays; caudalfin length is the length of the longest median ray; pelvic-fin length is the length of the longest ray on the ocular side. Lateral-line scales are counted on the ocular side from directly above the upper end of the gill opening to the base of the caudal fin; the counts of the number of scales above and below the lateral line are the highest obtained in an oblique row between the base of these fins and the lateral line.

Data in parentheses in the description refer to paratypes. Proportions in the text are rounded to the nearest $0.05 \mathrm{~mm}$.

\section{KEy TO THE hawaIIAN sPecies of Aseraggodes}

1a. No caudal peduncle; dorsal- and anal-fin rays with a broad, membranous ridge extending from base of each ray and gradually narrowing to ray tip; anal-fin rays 54-61; lateralline scales 60-66; ocular side with prominent dark blotches in three rows, the middle row of just two blotches, the largest and darkest....................... therese

1b. Caudal peduncle present; dorsal- and anal-fin rays with a thin, membranous ridge on some rays, not extending more than halfway to ray tip; anal-fin rays $47-52$; lateralline scales 66-80; ocular side without large, prominent dark blotches ............. 2

2a. Branched caudal-fin rays 16; lateral-line scales 66-70; head length 3.8-4.2 in SL; body very thin, the thickness $3.0-3.65$ in head length; size to $102.8 \mathrm{~mm}$ SL...... borebami

2b. Branched caudal-fin rays 14; lateral-line scales 76-80; head length 4.2-4.6 in SL; body thickness $2.5-3.0$ in head length; size to $58.6 \mathrm{~mm}$ SL .............. bolcomi, n. sp.

Aseraggodes bolcomi Randall, n. sp.

Figures 1, 2; Tables 1, 2

HOLOTYPE: вРвм 38448, mature female, $58.6 \mathrm{~mm}$, Hawaiian Islands, $\mathrm{O}^{\prime} \mathrm{ahu}$, off Ala Moana Beach Park, sand near a rock wall, 0.6 $\mathrm{m}$, hand net, Darrell Takaoka, 20 December 1997.

PARATYPES: NSMT-P.60933， $35.9 \mathrm{~mm}$, Hawaiian Islands, $\mathrm{O}^{\prime} \mathrm{ahu}$, north shore, Pūpūkea, sand, $10 \mathrm{~m}$, caught by hand, R. R. Holcom, early August 1997; BPBM 37852, 36.0 $\mathrm{mm}$ and CAS $214207,25.5 \mathrm{~mm}$, same data as preceding except depth $27 \mathrm{~m}$, and date 11 October 1997; USNM $365371,36.1 \mathrm{~mm}$, same data as preceding except depth, $10 \mathrm{~m}$; MNHN 2001-1113, 47.5 mm, O'ahu, Kāne'ohe Bay, off Marine Base, sand patch in reef, $2 \mathrm{~m}$, rotenone, D. W. Greenfield and J. E. Randall, 10 May 2000.

DIAGNOSIS: Dorsal-fin rays 68-75; analfin rays $47-50$; branched caudal-fin rays 14 ; pelvic-fin rays 5; lateral-line scales 76-80; body depth $2.2-2.55$ in SL; head length $4.2-$ 4.6 in SL; body thickness $2.5-3.0$ in head length; snout not overlapping upper lip; ocular side of large specimens pale brown with small, dark brown flecks; small specimens with irregular lines forming a reticular pattern; largest specimen, $58.6 \mathrm{~mm}$ SL.

DESCRIPTION: Dorsal-fin rays $70(68-75)$; anal-fin rays 47 (48-50); dorsal and anal-fin rays vary from all branched in holotype to none branched in smallest paratype, the last ray of each fin not connected by membrane to caudal peduncle; caudal-fin rays 18 , the median 14 rays branched; no pectoral fins; pelvic-fin rays 5 , the rays of ocular-side fin vary from all branched in holotype to none branched in smallest paratype; first and fifth rays of blind-side pelvic fin of holotype unbranched (all unbranched on smallest paratype); basal half of last rays of pelvic fins connected by membrane to abdomen; lateralline scales 77 (76-80); scales above lateral line 30 (29-33); scales below lateral line 29 (2833); no gill rakers, the inner edge of first gill arch a thin membrane; vertebrae $9+27$ $(9+26-27)$; first neural spine strongly arched over cranium; first 2 dorsal pterygiophores 
TABLE 1

Counts of Dorsal- and Aual-fin Rays and Lateral-line Scales of Hawaiian Species of Aseraggodes

\begin{tabular}{|c|c|c|c|c|c|c|c|c|c|c|c|c|c|c|c|c|c|c|c|c|c|}
\hline \multirow[b]{2}{*}{ Species } & \multicolumn{21}{|c|}{ Dorsal-fin Rays } \\
\hline & \multicolumn{2}{|r|}{68} & \multicolumn{2}{|c|}{69} & \multicolumn{2}{|c|}{70} & 71 & \multicolumn{2}{|r|}{72} & \multicolumn{2}{|c|}{73} & \multicolumn{2}{|c|}{74} & 75 & \multicolumn{2}{|c|}{76} & \multicolumn{2}{|c|}{77} & \multicolumn{2}{|c|}{78} & 79 \\
\hline \multirow{5}{*}{$\begin{array}{l}\text { A. borebami } \\
\text { A. bolcomi } \\
\text { A. therese }\end{array}$} & & & & & & & 2 & & 2 & & & 1 & & 2 & & 1 & & & & & \\
\hline & & 1 & & 1 & 1 & & 1 & & 1 & & & & & 1 & & & & & & & \\
\hline & & & & & & & & & 2 & & & 5 & & 5 & & 7 & & 4 & 2 & & 1 \\
\hline & \multicolumn{21}{|c|}{ Anal-fin Rays } \\
\hline & 4 & 47 & 48 & 49 & & 50 & 51 & 5 & 2 & 53 & 54 & & 55 & 56 & 5 & 7 & 58 & 59 & & 60 & 61 \\
\hline \multirow{4}{*}{$\begin{array}{l}\text { A. borebami } \\
\text { A. bolcomi } \\
\text { A. therese }\end{array}$} & & $y$ & . & 1 & & 2 & 2 & 6 & 6 & & & & & & & & & & & & \\
\hline & & & 1 & & & & & & & & 3 & & & 7 & 9 & & 5 & 2 & & & 1 \\
\hline & \multicolumn{21}{|c|}{ Lateral-line Scales } \\
\hline & 60 & 61 & 62 & 63 & 64 & 65 & 66 & 67 & 68 & 69 & 70 & 71 & 72 & 73 & 74 & 75 & 76 & 77 & 78 & 79 & 80 \\
\hline A. borehami & & & & & & & 1 & 2 & 3 & 3 & 2 & & & & & & & & & & \\
\hline $\begin{array}{l}\text { A. bolcomi } \\
\text { A. therese }\end{array}$ & 2 & 2 & 2 & 4 & 8 & 5 & 2 & & & & & & & & & & 2 & 1 & 1 & 1 & 1 \\
\hline
\end{tabular}

joined except distally where one branch goes to first dorsal-fin ray and the shorter second branch to space between second and third rays; basal end of third and fourth dorsal pterygiophores off tip of first neural spine, the third leading to space between third and fourth dorsal rays, and the fourth to between fourth and fifth dorsal rays; next 7 dorsal pterygiophores from between first and second neural spines, each to base of a dorsal ray (or slightly posterior to it); space between second and third neural spines and between third and fourth neural spines with 3 dorsal pterygiophores each.

Body oval and moderately elongate, the depth $2.5(2.2-2.55)$ in SL, increasing with growth; body thin, the thickness $2.5(2.7-3.0)$ in head length; head symmetrically rounded anteriorly, its length $4.6(4.2-4.45)$ in SL; snout length 4.3 (4.05-4.6) in head length; diameter of upper eye $5.6(4.25-5.5)$ in head; posterior edge of upper eye in vertical alignment with anterior edge of pupil of lower eye (varies from slightly posterior to anterior edge of lower eye in smallest paratype to posterior to middle of eye in largest); interorbital space scaled (about 7 rows of scales between eyes) and concave, the least width $8.4(6.8-10.9)$ in head; upper end of gill opening at level of ventral edge of lower eye; caudal-peduncle depth $1.65(1.65-1.75)$ in head; caudal-peduncle length 6.05 (5.75-7.7) in head.

Mouth inferior, the jaws strongly curved; upper lip not overlapping the lower; maxilla ending below anterior edge of pupil of lower eye, the upper-jaw length (more easily measured on blind side) $2.8(2.7-2.85)$ in head; a band of small villiform teeth posteriorly in jaws in about 8 rows at greatest width; lips of blind side strongly plicate; anterior nostril of ocular side a large, tapering, membranous tube in front of upper edge of lower eye, nearly reaching eye when laid back; posterior nostril a ventrally directed slit in labial groove at anteroventral edge of lower eye; anterior nostril of blind side a tapering, membranous tube at edge of labial groove above middle of upper jaw; posterior nostril of blind side a short, membranous tube dorsoposterior to anterior nostril, the internarial distance about half orbit diameter.

Lateral line of ocular side straight to above upper end of gill opening, then ascending 


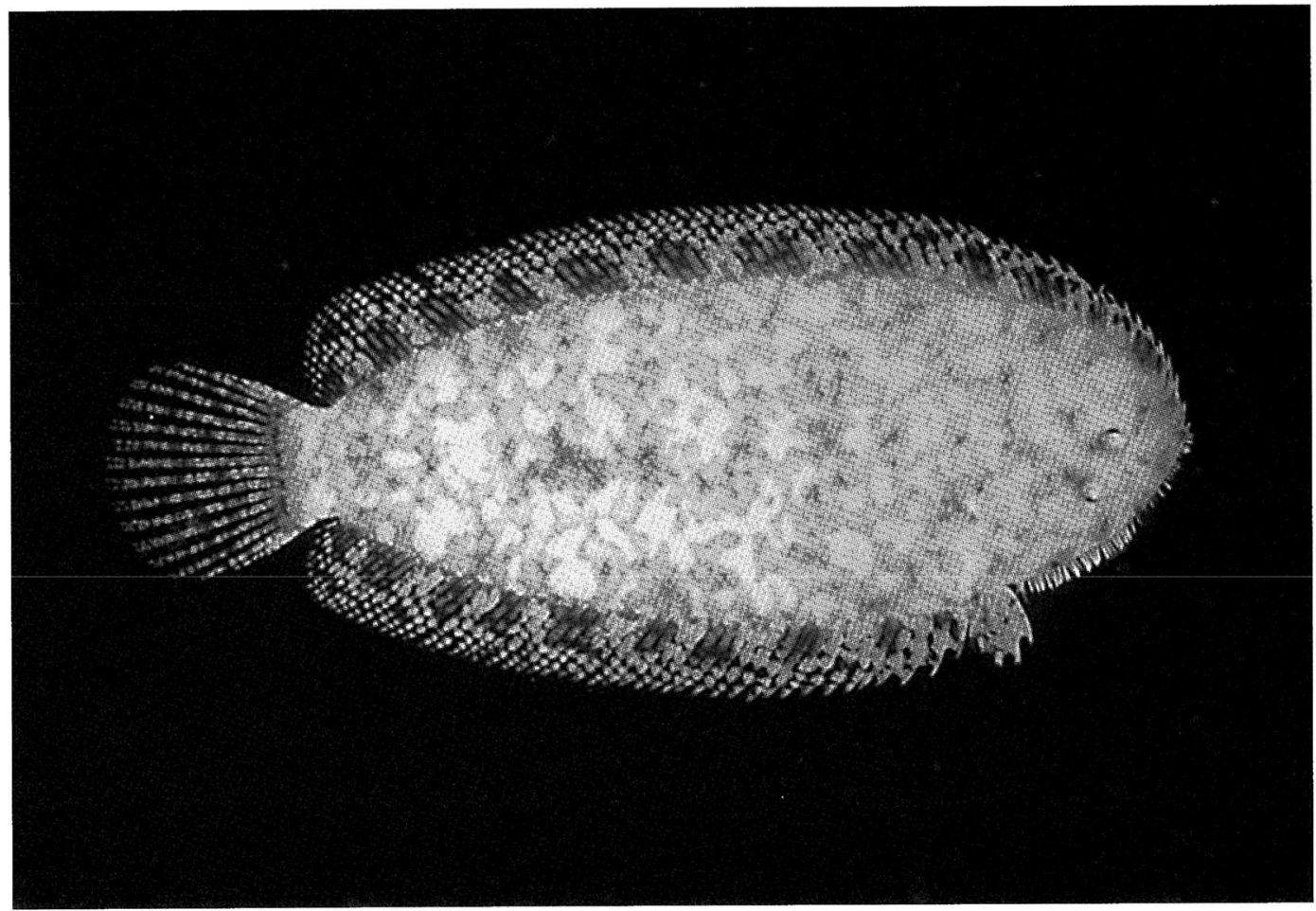

FigURE 1. Holotype of Aseraggodes bolcomi, female, вPвм 38448, $58.6 \mathrm{~mm}$ SL, O'ahu, Hawaiian Islands.

slightly as it continues anteriorly to within 1.5 eye diameters of upper eye; two pored lateralline scales on caudal-fin base posterior to end of hypural plate; an apparent straight lateral line on blind side, but pores not detected; an indistinct dorsoanterior branch of lateral line on blind side of head extending in holotype to about base of 37 th dorsal-fin ray. Scales ctenoid on both sides of body except those of lateral line, which are embedded and lack cteni; exposed part of scales of ocular side nearly twice as wide as long (disregarding length of cteni), the cteni in middle of scales long, about equal to length of exposed part of scales; number of cteni on scales of ocular side of holotype 11-13 (about 8 in small paratypes); scales anteriorly on snout of ocular side embedded and without cteni; scales of blind side anterior to rear edge of maxilla fleshy and without cteni, those near mouth as short, fleshy papillae; base of dorsal and anal fins scaled, but scales not extending out on rays except those on head where small, isolated, with fewer cteni, and reduced outwardly to small papillae; basal third of caudal fin scaled. Anal-fin rays and dorsal-fin rays posterior to head with a low membranous ridge extending at most halfway to ray tips, this ridge progressively shorter posteriorly and variably absent there; some membranous ridges of holotype and largest paratype with dark brown cirri; a fringe of prominent cirri on front of snout and ventral edge of head.

Dorsal-fin origin (base of first dorsal ray) directly anterior to interorbital space, but also with a fleshy papillate ridge continuing to front of upper lip; first dorsal-fin ray 3.15 $(2.85-3.4)$ in head; longest dorsal-fin ray (many rays near middle of fin subequal) 1.75 $(1.45-1.7)$ in head; origin of anal fin onethird orbit diameter behind posterior end of gill opening; first anal-fin ray $2.8(2.55-2.9)$ in head; longest anal-fin ray $1.75(1.45-1.7)$ in head; caudal fin rounded, $4.45(3.6-3.9)$ in 


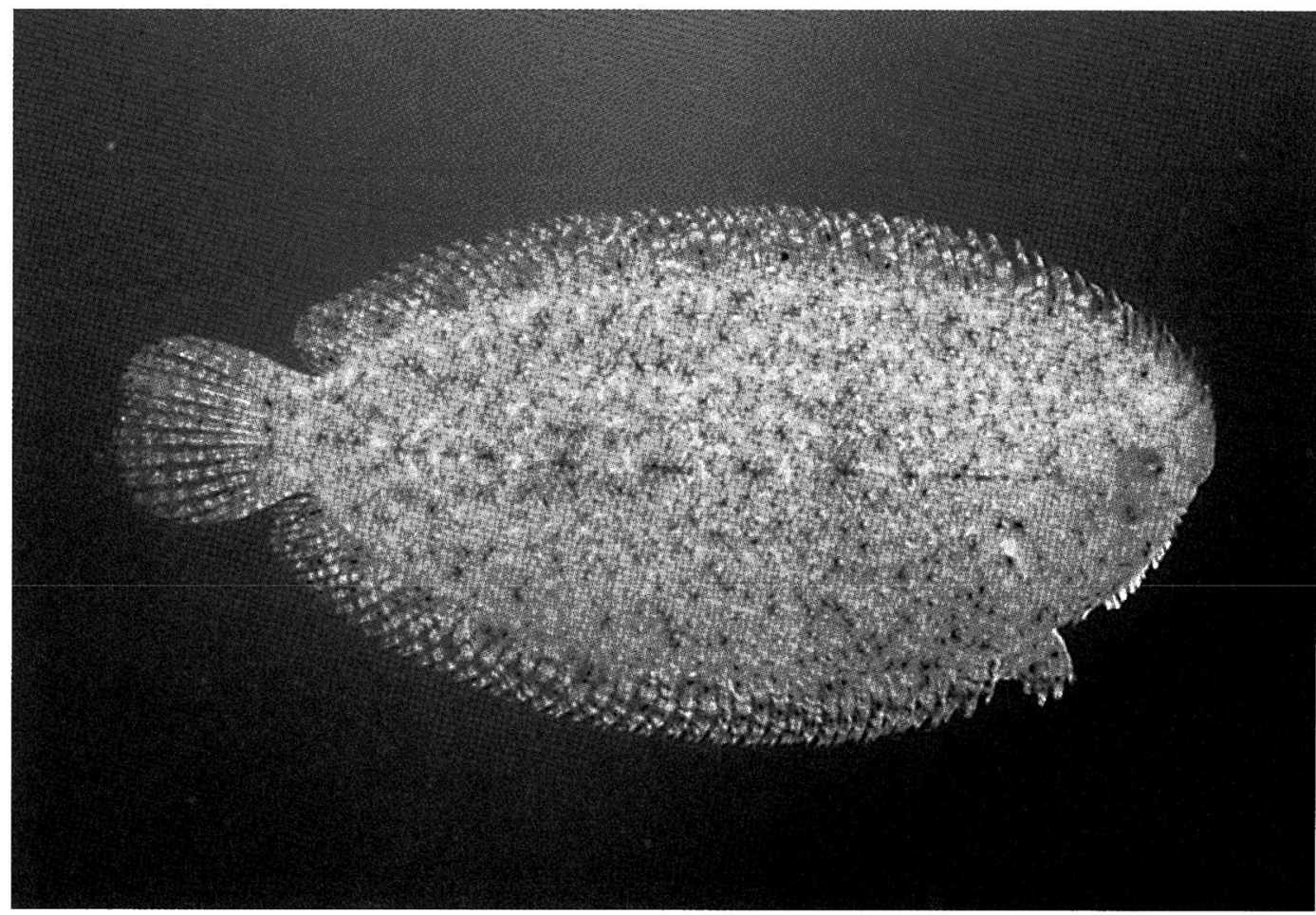

FIGURE 2. Paratype of Aseraggodes bolcomi, male, ввPM $37852,36.0 \mathrm{~m} \mathrm{SL}$, O'ahu, Hawaiian Islands.

SL; ocular-side pelvic fin longer and slightly anterior to fin of blind side, the third ray longest, $2.1(1.85-1.95)$ in head.

Color of holotype, a mature female, in alcohol: ocular side pale yellowish brown with numerous brown flecks from dark pigment mainly on edges of clusters of scales, some flecks conjoined to form short, irregular lines; darkest flecks a series along lateral line forming obscure dashes; dorsal and anal fins with translucent membranes, the rays with scattered small brown spots, mainly near base; scaled basal third of caudal fin colored like body; rest of fin with translucent membranes, the rays with small brown spots arranged to form four, faint, irregular, transverse lines; ocular-side pelvic fin with a few small brown spots basally on rays; head and body of blind side uniformly whitish.

Color of holotype when fresh: ocular side light brown with dark brown flecks as described for preserved specimen, but with nu- merous small irregular whitish blotches; eyes bronze; rays of dorsal and anal fins with scattered small dark brown spots and more numerous and larger whitish blotches extending laterally onto otherwise transparent membranes; a series of large transparent spots on basal half of dorsal and anal rays where white blotches absent and rays faintly purplish; caudal fin with small dark brown spots on rays as described for specimen in alcohol and white blotches more confined to rays than on dorsal and anal fins; blind side white.

Color of $36.0-\mathrm{mm}$ paratype, a mature male, in alcohol: ocular side pale yellowish with a faint reticular pattern of irregular fine, brown lines, the dark pigment on scale edges, and small, very irregular brown blotches in approximately three rows (dorsal, lateral, and ventral); largest dark blotch bilobed and midlateral, about halfway between gill opening and end of caudal fin; a brown line across basal fifth of caudal fin, the pigment only 
TABLE 2

Proportional Measurements of Type Specimens of Aseraggodes bolcomi Expressed as Percentages of the Standard Length

\begin{tabular}{|c|c|c|c|c|c|}
\hline \multirow[b]{2}{*}{ Character } & \multirow{2}{*}{ 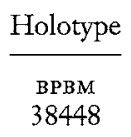 } & \multicolumn{4}{|c|}{ Paratypes } \\
\hline & & $\begin{array}{c}\text { CAS } \\
214207\end{array}$ & $\begin{array}{l}\text { BPBM } \\
37852\end{array}$ & $\begin{array}{l}\text { USNM } \\
365371\end{array}$ & $\begin{array}{c}\text { MNHN } \\
01-113\end{array}$ \\
\hline Sex & female & $?$ & male & male & female \\
\hline Standard length $(\mathrm{mm})$ & 58.6 & 25.5 & 36.0 & 36.1 & 47.5 \\
\hline Body depth & 45.3 & 39.3 & 40.3 & 40.2 & 44.2 \\
\hline Body thickness & 8.7 & 7.8 & 8.0 & 8.3 & 8.3 \\
\hline Head length & 21.8 & 22.4 & 23.9 & 22.6 & 23.0 \\
\hline Snout length & 5.1 & 4.3 & 5.2 & 5.6 & 5.1 \\
\hline Eye diameter & 3.9 & 4.5 & 4.2 & 5.3 & 4.2 \\
\hline Interorbital width & 2.6 & 3.3 & 2.8 & 2.5 & 2.1 \\
\hline Upper-jaw length & 7.7 & 8.2 & 8.3 & 8.3 & 8.4 \\
\hline Caudal-peduncle depth & 13.1 & 13.7 & 13.8 & 13.9 & 13.2 \\
\hline Caudal-peduncle length & 3.6 & 3.9 & 3.1 & 3.1 & 3.8 \\
\hline Predorsal length & 4.3 & 4.9 & 5.3 & 5.3 & 5.7 \\
\hline Preanal length & 25.5 & 24.0 & 23.9 & 23.8 & 25.4 \\
\hline Prepelvic length & 19.5 & 20.9 & 19.2 & 18.8 & 19.4 \\
\hline First dorsal ray & 6.9 & 7.9 & 7.0 & 7.7 & 6.9 \\
\hline Longest dorsal ray & 12.5 & 15.5 & 14.0 & 15.5 & 14.4 \\
\hline First anal ray & 7.8 & 8.8 & 8.3 & 8.9 & 8.7 \\
\hline Longest anal ray & 12.5 & 15.6 & 14.0 & 15.2 & 14.5 \\
\hline Caudal-fin length & 22.4 & 25.5 & 25.5 & 27.7 & 25.6 \\
\hline Pelvic-fin length & 10.4 & 11.7 & 11.3 & 12.2 & 11.8 \\
\hline
\end{tabular}

on rays; scattered small brown spots on rays of dorsal and anal fins, the membranes transparent. The $36.1-\mathrm{mm}$ paratype has only the reticular pattern with three faint dark blotches in the midlateral line.

Color of $36.0-\mathrm{mm}$ paratype when fresh: light brown with the reticular pattern and dark blotches as described for the specimen in alcohol, but notably different in having many large, irregular whitish blotches on head and body, the dark edges of which are part of the reticular pattern; eyes brassy yellow; lower half of dorsal and anal fins with a series of large blotches (more evident than on holotype), 12 in the dorsal and 10 in the anal, in which the rays are purplish and the membranes hyaline; rays outside blotches white with extensions of white into adjacent membranes, and a few scattered brown spots. The black of the fin membranes in Figure 2 is the result of the black background showing through the transparent fins; rays of caudal fin banded with purplish, the membranes clear; pelvic fins white with a few small transparent spots.

ETYMOLOGY: This species is named for Ronald R. Holcom, who collected four of the six type specimens and was the first to recognize this species as different from the other Hawaiian species of Aseraggodes.

REMARKS: Aseraggodes bolcomi is currently known only from the island of $\mathrm{O}^{\prime}$ ahu; the specimens were collected from sand in the depth range of 0.6 to $27 \mathrm{~m}$.

Chabanaud (1930) reviewed the species of Aseraggodes and recognized 15 species. Randall (1996) reviewed the literature after Chabanaud. There are now the following shallowwater marine species from insular localities of the western and central Pacific: A. melanostictus (Peters, 1877) from Bougainville; $A$. kobensis (Steindachner, 1896) from Japan; $A$. filifer Weber, 1913 from Indonesia and the Philippines, unique in the flamentous first dorsal-fin ray; $A$. smithi and A. whittakeri, both described from the Marshall Islands by 
Woods in Schultz and Collaborators (1966), in addition to a specimen identified as $A$. melanostictus "with uncertainty"; $A$. babamondei Randall \& Meléndez, 1987 from Easter Island and Lord Howe Island; and A. borebami and A. therese described by Randall (1996) from Hawaici.

The collective meristic data of $A$. bolcomi separate it from all described species of the genus. It is surprising that, of the known species, it seems closest to the Hawaiian $A$. borebami, sharing with it most morphometric measurements, having overlapping dorsal and anal fin-ray counts, the same jaw structure, and a similar color pattern. It differs, as noted in the key, by having 14 instead of 16 branched caudal-fin rays, an unusually high count of 76-80 lateral-line scales, and smaller size.

As noted by Randall (1996), a reappraisal is needed of the generic classification of the Aseraggodinae, a subfamily proposed by Ochiai (1963). In a review of that publication, Hubbs (1967) was critical of the classification, pointing out that it was based solely on a study of genera occurring in Japan. In addition, there are many specimens of soles on museum shelves identified only as Aseraggodes sp. that need to be studied.

Randall and Meléndez (1987) noted that a milky white substance was exuded by Aseraggodes babamondei from the edges of its body when it was collected at Easter Island. They demonstrated that this substance is toxic by causing the death of three individuals of the tidepool goby Kelloggella oligolepis. Although a similar exudate has not been noticed from the three Hawaiian species of Aseraggodes, an observation of $A$. therese suggests the presence of a crinotoxin in that species. Two individuals of the jack Caranx melampygus were eating small fishes that had been killed by rotenone. A freshly $\operatorname{dead} A$. therese was picked off the substratum by J.E.R. and released in the path of the jacks. Each took the sole into its mouth, but each quickly ejected it, suggesting that it was unpalatable.

\section{ACKNOWLEDGMENTS}

Thanks are due Ronald R. Holcom, Darrell Takaoka, and David W. Greenfield for col- lecting specimens of the new Hawaiian species of sole, and to Greenfield for radiographs of the specimens.

\section{Literature Cited}

Chabanaud, P. 1930. Revision du genre Aseraggodes Kaup. Zool. Meded. (Leiden) 13:180-192.

Gilbert, C. H. 1905. The aquatic resources of the Hawaiian Islands. Part II. Section II.-The deep-sea fishes. Bull. U.S. Fish Comm. 23 (1903): $x i+575-713$.

Gosline, W. A., and V. E. Brock. 1960. Handbook of Hawaiian fishes. University of Hawai'i Press, Honolulu.

Hubbs, C. L. 1967. Fauna Japonica/Soleina (Pisces). Copeia 1967 (2): 490-491.

Ochiai, A. 1963. Fauna Japonica Soleina (Pisces). Biographical Society of Japan, Tokyo.

Peters, W. 1877. Übersicht der während der von 1874 bis 1876 unter dem Commando des Hrn. Capitän z.S. Freiherrn von Schleinitz ausgeführten Reise S.M.S. "Gazelle" gesammelten und von der Kaiserlichen Admiralität des Königlichen Akademie der Wissenschanten übersandten Fische. Montasber. Akad. Wiss. Berl. 1876:831-854.

Randall, J. E. 1996. Two new soles of the genus Aseraggodes (Pleuronectiformes: Soleidae) from the Hawaiian Islands. Pac. Sci. 50:427-440.

Randall, J. E., and R. Meléndez. 1987. A new sole of the genus Aseraggodes from Easter Island and Lord Howe Island, with comments on the validity of $A$. ramsaii. Bishop Mus. Occas. Pap. 27:97-105.

Schultz, L. P., and Collaborators. 1966. Fishes of the Marshall and Marianas Islands. Bull. U.S. Natl. Mus. 202, vol. 3: vii + 176 pp.

Steindachner, F. 1896. Bericht über die während der Reise Sr. Maj. Schiff "Aurora" von Dr. C. Ritter v. Microszewski in den Jahren 1895 und 1896, gesammelten Fische. Ann. Naturhist. Hofmus. Wien 11:197-230.

Weber, M. 1913. Die Fische der SibogaExpedition. E. J. Brill, Leiden. 